\title{
Soberania da imago e o retorno da linguagem em geral \\ (de Nietzsche a Derrida e além)
}

João C. Galvão Jr. ${ }^{1}$

Resumo. A proposta deste trabalho é estabelecer uma ponte entre o poder da soberania da imago e a força da linguagem em geral. Por imago entendemos um complexo de imagens arcaicas cristalizadas da ordem do inconsciente e sua tradição ocidental do pensamento da representação. Por linguagem em geral entendemos toda tradição da linguagem para além de sua cristalização e fonemática humana. Daí resulta a destruição destas cristalizações e a abertura para um pensamento do retorno da linguagem em geral. Acreditamos que o pensamento derridiano não dá conta da "linguagem animot" e que esta posição estaria muito mais próxima do pensamento ou ação benjaminiana. Por outro lado trava-se aqui o encontro impetuoso entre Jung e Benjamin.

Palavras-chave. Imago, inconsciente humano, animalidade, animot, destrutividade.

Résumé. La proposition de cette étude est d'établir un pont entre le pouvoir de la souveraineté du imago et la force du langage en général. Pour imago nous comprenons un complexe des images archaïques cristallisées de l'ordre de l'inconscient et de sa tradition occidentale de la pensée de la représentation. Par langage en général, nous comprenons toute la tradition du langage au-delà de sa cristallisation et phonématique humaine. D'où résulte la destruction de cettes cristallisations et l'ouverture d'une pensée pour le retour du langage en général. Nous croyons que la pensée derridienne ne tient pas compte du «langage animot » et que cette position serait beaucoup plus proche de la pensée et de l'action benjaminienne. De l'autre côté, c'est ici que la rencontre impétueuse entre Jung et Benjamin s'entame.

Mots-clés. Imago, inconscient humain, animalité, animot, destructivité.

\footnotetext{
${ }^{1}$ Formação Freudiana - FF/Rio de Janeiro, doutor em Ciência Política - UFF/Instituto de Ciências Humanas e Filosofia.

Este ensaio foi escrito a partir das notas que me orientaram nos encontros "Entre a desconstrução derridiana e a destruição benjaminiana" que realizei na Formação Freudiana FF/Rio de Janeiro, em 12 - 19 de novembro de 2009.
} 
Não invistas com raiva ou com intenção destrutiva contra o que se tornou. $O$ que queres colocar em seu lugar? Quando consegues destruir o que se tornou, não sabes que voltarás contra ti mesmo a vontade de destruir? Mas cada qual que faz da destruição seu objetivo, perecerá através da autodestruição. É muito melhor levar bem em consideração o que se tornou, pois o respeito é uma bênção. Depois disso volta-te para os mortos, ouve suas queixas e vai ao encontro deles com amor. Não sejas seu porta-voz deslumbrado, como aquele profeta furioso que não sabia de quem era a causa que estava defendendo, mas acreditava que falava a partir de si mesmo, e se considerava a vontade de destruição; há profetas que no final se apedrejam a si mesmos.

C. G. Jung, Nox secunda $[\text { Segunda noite }]^{2}$

O fim do mundo - a destruição e libertação de uma representação

(dramática).

W. Benjamin, Mundo e Tempo ${ }^{3}$

2 JUNG. C.G. O Livro Vermelho: Liber Novus. Trad. Edgar Orth. Petrópolis: Vozes, 2010, p. 297 (Incluído o esboço. Nota de rodapé 185).

${ }^{3}$ BENJAMIN, W. Mundo e Tempo (1919) (Fragmentos: Filosofia da História e Política). In $O$ Anjo da História. Trad. João Barrento. Lisboa: Assírio \& Alvim, 2010, vol. 4, p. 29 (Versão preparatória do ensaio perdido sobre "O Verdadeiro Político"). 
Num mundo humano [o cenário da História], em seu drama, o filhote de homem, não ainda tão humano em sua humanidade já reconhece sua imagem no espelho.

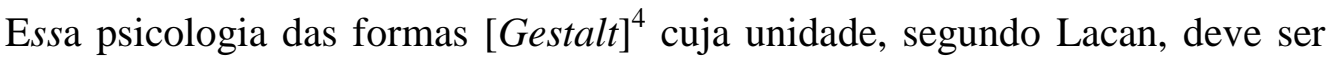
considerada como ligada à espécie - próprios à sua espécie $^{5}$ - simboliza a origem imaginária do inconsciente e o automatismo de formas inscrito no campo da linguagem, ligado a lógica das imagos mentais. Muito embora o conceito de imago como complexo de imagens tenha sido introduzida por Jung, para Lacan, o antigo termo, reflete uma identificação com a forma pela qual o outro semelhante se inscreve. A imagem enquanto Gestalt vai estruturar o homem em humano, enviando-o a um complexo identificatório com o outro. Nesse sentido, a matemática é certeira e dialoga com a História oficial, palavras são como números e a linguagem como matemática. A operação no estabelecimento daquilo que amarra o exercício da imaginação do poder na condução dos homens ou suas figuras.

Mas há fatos criados por estes complexos (reunião de conteúdos, constelação, grupos de sentimentos, pensamentos, lembranças) ignorados e que, entretanto, influenciam poderosamente a vida por serem inconscientes. Nesta leitura, este filhote humano está preso ao passado da espécie, um reservatório de imagens da origem, herdando tais imagens do passado ancestral, passado que inclui todos os antecessores humanos. Este "espírito coletivo" 6 tem a duração que pode ser calculada em séculos; uma marca do "espírito dos tempos"7 que, enquanto tal, permanece inconsciente para

\footnotetext{
${ }^{4}$ LACAN, J. Le stade du miroir comme formateur de la fonction du Je (1936 - 1949) In Écrits. Paris: Seuil, 1966, p. 95. Ver também JUNG. C.G. O Hino ao Criador. In Símbolos da Transformação - Análise dos prelúdios de uma esquizofrenia (1952) Trad. Eva Stern. Petrópolis: Vozes, 1995, p. 53 - 55. Texto que tem seu início em 1911, C. G. Jung já fazia referência a figura [Gestalt] enquanto imagem psíquica, um complexo de representações. A figura de Deus como uma imagem psíquica; figura [Gestalt] religiosa ou figura [Gestalt] divina como um fator psíquico.

${ }_{5}^{5}$ Em sua teoria psicanalítica "apolítica", tudo indica que Lacan, sem mencionar a Suma Teológica de Tomás de Aquino, vai buscar esta expressão ("espécie"), não menos ideológica, no medievo, na Questão 35 A Imagem, do referido Livro. Ver AQUINO, T. A Imagem. In Suma Teológica (Summae Theologiae). São Paulo: Loyola, 2003, vol. I, p. 587.

${ }^{6}$ JUNG. C.G. Anos de Estudo. In Memórias, Sonhos, Reflexões. Trad. Dora Ferreira da Silva. Rio de Janeiro: Nova Fronteira, 1988, p. 88.

${ }^{7}$ JUNG. C.G. O Caminho Daquele que Virá. In O Livro Vermelho: Liber Novus. Trad. Edgar Orth. Petrópolis: Vozes, 2010, p. 229.
} 
a maioria destes "homens" ou massas humanas. "O que significa para vós o espírito dos tempos, isto é no fundo o espírito do próprio Senhor [Mestre], no qual os tempos se espelham". ${ }^{8}$ O que está em jogo aqui é a soberania da imagem [la souveraineté de l'image $;{ }^{9}$ o controle interiorizado das massas em seu reflexo no espelho.

Mas, de qual “inconsciente” Lacan está falando? Do inconsciente humano [L inconscient humain $].{ }^{10}$ Nesse sentido, quando fala - fala demais - quando Lacan fala, fala de uma linguagem que evoca a ordem humana [l'ordre humain]. "Car la fonction du langage n'y est pas d informer, mais d evoquer." ${ }^{12}$ O poder de nomear - ser nomeado e nomear. Chamar e dizer o nome de [alguém]; aguardando comunicação, aproximação ou indicação de presença - evoquer. Nesse mesmo sentido - de um sentido pré-existente que determina todas as coisas - fecha as portas de uma civilização ou cidade ao considerado "animal".

A animalidade não pode comungar com a estrutura humana. Ou em outra ordem: a estrutura humana não pode comungar com a animalidade. A esta "estrutura humana" fundamenta-se a origem de uma estrutura transcendental ["símbolo transcendental"] ${ }^{13}$ no domínio imaginário. Analogia do pensamento de Santo Tomás de Aquino e a psicologia de C. G. Jung revelado por Father White. ${ }^{14}$ "Os animais de espécies diferentes têm figuras diferentes, mas não cores diferentes. Por isso, se se pinta sobre a parede a cor de alguma coisa não se chama a isso imagem, mas somente se se pinta sua figura". ${ }^{15}$ Nesta leitura, se diz que estas imagens - que já é uma Gestalt [ou evocação pelo "psychologue gestaltiste"16] - são a espécie de algo humano e civilizacional [cultural].

\footnotetext{
${ }^{8}$ Idem. Citação de Jung ao Fausto de Goethe.

${ }^{9}$ BIRMAN, J. Je suis vu, donc je suis: la visibilité en question. In Les Tyrannies de la visibilité. Paris: Érès, 2011, p. 43.

${ }^{10}$ DERRIDA, J. Et si l'animal répondait? In L'animal que donc je suis. Paris: Galilée, 2006, p. 165 .

${ }^{11}$ Idem, p. 170.

${ }^{12}$ Idem, p. 171.

${ }^{13}$ JUNG. C.G. O Hino ao Criador. In Símbolos da Transformação - Análise dos prelúdios de uma esquizofrenia (1911) Trad. Eva Stern. Petrópolis: Vozes, 1995, p. 57.

${ }^{14}$ JUNG. C.G. Cartas (1946 - 1955). Trad. Edgar Orth. Petrópolis: Vozes, 2002, vol. 2, p. 17.

${ }^{15}$ AQUINO, T. A Imagem (Questão 35). In Suma Teológica (Summae Theologiae). São Paulo: Loyola, 2003, vol. I, p. 587.

${ }^{16}$ LACAN, J. Propos sur la causalité psychique (1946) In Écrits. Paris: Seuil, 1966, p. 166.
} 
Relaciona-se com a imagem do ser humano [image de l'être humain] ${ }^{17} \mathrm{o}$ reconhecimento da forma humana [forme humaine $]^{18}$ e identificação com esta forma.

A nomeada "Gestalttheorie" possui sua missão na História imemorial dessa imagem. Fazem com que os considerados humanos se lembrem do estádio do espelho ou fase do espelho [phase du miroir] ${ }^{19}$ evocado em 1936 por J. Lacan, "pela virtude da imagem e da operação do espírito santo da linguagem" [par la vertu de l'image et l'opération du saint esprit du langage].

"Veja", dizem, "isso faz pensar naquela famosa história de Lacan, o estádio do espelho. Que era mesmo que ele dizia, exatamente?"20

\section{Que existem humanos e não humanos.}

Nesta não humanidade os arquivos apagados das forças demoníacas. Assim foi com a horda dos hunos, 300 depois de Cristo; da mesma forma, com a horda dos mongóis, 1000 anos depois - ambos excluídos das portas desta "civilização" [cultura], da Cidade de Deus nesta História oficial linear ou imemorial. O mundo humano - o cenário da História. Como falará o Mestre da razão G.W.F. Hegel: a História dada pela providência divina. Isso [não] rememorando os povos exterminados ou intensidades apagadas por esta "civilização" - "civilização branca e cristã", ${ }^{21}$ expressão que Freud utiliza-se no Futuro de uma ilusão. "Os animais selvagens e perigosos foram exterminados e a criação de animais domésticos floresce". ${ }^{22} \mathrm{O}$ animal domesticado, o animal que fala, fala em sua fala logocêntrica: o inconsciente humano "lacaniano".

$\mathrm{O}$ animal domesticado traduzido no inconsciente do homem humanizado.

\footnotetext{
${ }^{17}$ Idem, p. 185.

${ }^{18}$ Idem, p. 186.

${ }^{19}$ Idem, p. 184.

${ }^{20}$ "Tiens, se dit-on, cela fait penser à cette fameuse histoire de Lacan, le stade du miroir. Qu'est-ce qu'il disait donc exactement?" LACAN, J. Propos sur la causalité psychique (1946) In Écrits. Paris: Seuil, 1966, p. 186.

${ }^{21}$ FREUD, S. El porvenir de una Ilusión. Trad. José L. Etcheverry. In Obras Completas. Buenos Aires / Madrid: Amorrortu, 2007, vol. 21, p. 20.

${ }^{22}$ FREUD, S. El malestar en la Cultura. Trad. José L. Etcheverry. In Obras Completas. Buenos Aires / Madrid: Amorrortu, 2007, vol. 21, p. 91.
} 
"Falar" do animot ${ }^{23}$ ou dos animais é complicado (o que seria importante registrar desde já com Derrida da não possibilidade de separação do "animal" e do homem ou de sua animalidade). ${ }^{24} \mathrm{O}$ homem não é um ser diverso dos animais ou superior a eles ${ }^{25}$ e as funções psíquicas mais elevadas em nada mudam o fato de que o homem é um animal, em que a criação superior é inconcebível em si mesma e só podem conceber-se como funções dos instintos animais. ${ }^{26} \mathrm{O}$ animot não é um falar ou um ser falante, mas uma ação ou pensamento da ação, marcado pela destruição [a cada instante] como está sendo registrado. Portanto, falar de uma coisa que não é uma fala, mas, pura ação instintual ["violência pura-divina"], torna-se diante da fala uma causa missionária, neste falar, com o sério risco de extermínio deste animal ou animais forças espectrais e demoníacas.

Este ser em pé quer vir a ser linguagem fônica - quer aprender a falar - quer vontade de Estado, quer mitologia branca. Os animais se tornam estranhos. Mas, para além do ser em pé há o ser de quatro.

Ao abrir as portas ${ }^{27}$ para os animais, vários pensadores marcaram relações de forças com a cidade (incluo aqui a Cidade de Deus [Santo Agostinho] - pensamento da representação) que fecha suas portas para com estes animais. Vários, não muitos, talvez poucos, eventualmente alguns. Poucos pensadores. Pouca Filosofia. Pouco pensar.

O Zaratustra de Nietzsche, ao soltar os animais, ao afirmar o pensamento do eterno retorno ${ }^{28}$ - ético - afirma a diferença da potência dos animais. Pelo menos na

\footnotetext{
${ }^{23}$ A Derrida se deve já a inclusão de pelo menos três conceitos na linguagem da Filosofia: différance, desconstrução e animot. Animots, em francês, pronuncia-se exatamente da mesma maneira que Animaux (plural de animal). Registra-se, que o forjamento deste conceito, segue o mesmo procedimento de Différence e Différance, que só se distinguem na escritura e não na pronúncia. DERRIDA, J. O Animal que Logo Sou. Trad. Fábio Landa. São Paulo: UNESP, 2002, p. 70; L'animal que donc je suis. Paris: Galilée, 2006, p. 60.

24 "Il n'y a pas l'Animal au singulier général, séparé de l'homme". DERRIDA, J. L'animal que donc je suis. Paris: Galilée, 2006, p. 73.

${ }^{25}$ FREUD, S. Una dificultad del psicoanálisis (1916) Trad. José L. Etcheverry. In Obras Completas. Buenos Aires / Madrid: Amorrortu, 2007, vol. 17, p. 132.

${ }^{26}$ FERENCZI, S. Crítica de metamorfoses e símbolos da libido, de Jung. Trad. Álvaro Cabral. In Psicanálise II, Obras Completas. São Paulo: Martins Fontes, 2011, vol. 2, p. 106.

27 "A porta tem de ficar aberta". Seminário sobre a Técnica Psicanalítica. Notas do curso ministrado por Chaim Samuel Katz na Formação Freudiana - F.F, Rio de Janeiro, marçonovembro de 2010.

${ }^{28}$ Viver como se cada instante da vida fosse retornar eternamente; dar a intensidade no momento em que se vive; amar a vida com intensidade. NIETZSCHE. F. Ecce Homo: como alguém se torna o que é. Trad. Paulo César de Souza. São Paulo: Companhia das Letras, 2003, p. 82.
} 
esfera da arte da eloqüência, o que já é muito, se comparado ao Prometeu de Spitteler ou mesmo o Filêmon de Jung.

Entre meus amigos, só dois o aprovaram [o Zaratustra] abertamente: um acabou por suicidar-se em 2009 no Maranhão e o outro afunda-se como um gênio ignorado pelo pensamento da representação nas cadeiras pontifícias de Filosofia da cidade "maravilhosa" [Rio de Janeiro]. Nietzsche me abrira uma porta e Zaratustra fechara outra. Reencontrei meus animais com Freud - retornando ao Zaratustra e seus animais instintuais. Nossos animais. Rememoro a cada instante esta animalidade com o Anjo da História.

Portanto, existe um complexo diálogo do Verdadeiro Político ("do lugar histórico-filosófico da liberdade,29) entre Zaratustra [Nietzsche] e o Anjo da História [Benjamin] com Prometeu [Spitteler] e Filêmon [Jung].

No momento, gostaríamos de deixar registrado este encontro impetuoso das forças demoníacas com o pensamento da representação.

Mas, institucionalmente [nas Universidades "laicas"] é inútil falar aos outros sobre coisas que não sabem ou hostilizam como pensadores da representação. Para mim o segundo Zaratustra é mais do que uma experiência filosófica. É uma experiência da alma.

Zaratustra $^{30}$ ao descer as montanhas, questionando o homem diante do macaco e logo do super-homem, sua dolorosa vergonha, e a necessidade de permanecer fiel a terra, não acreditando naqueles que falam de esperanças supra-terrestres. E Zaratustra "viu uma águia que pairava nos ares traçando largos rodeios e sustentando uma serpente que não parecia uma presa, mas um aliado, porque se lhe enroscava ao pescoço. - São os meus animais! Encontrei mais perigos entre os homens do que entre os animais. Guiem-me os meus animais"31 disse Zaratustra. E Nietzsche vai criar um diálogo com os animais - seus animais.

Fará o mesmo, Derrida, nas passagens das fronteiras entre o homem e o animal; passando estas fronteiras chegará ao animal e não a um passe - passe -

\footnotetext{
${ }^{29}$ BENJAMIN, W. Mundo e tempo (1919) (Fragmentos: Filosofia da História e Política). In $O$ Anjo da História. Trad. João Barrento. Lisboa: Assírio \& Alvim, 2010, vol. 4, p. 30 (Versão preparatória do ensaio perdido sobre "O Verdadeiro Político").

${ }^{30}$ NIETZSCHE. F. Assim Falava Zaratustra. Trad. José Mendes de Souza. São Paulo: Brasil editora, 1965, p. 6.

${ }^{31}$ Idem, p. 18.
} 
ideologizado que marcará um discurso falado e logocêntrico. O logocentrismo é antes de mais nada uma tese sobre o animal, sobre o animal privado de logos. Nas passagens desta fronteira, entre o homem e o animal, passando as fronteiras ou os fins do homem, Derrida chega ao animal, "ao animal em mim" [l animal en moi]. ${ }^{32} \mathrm{Um}$ "animal indeterminado" [animal indéterminé]: Derrida faz referência a Nietzsche. O indeterminismo do instinto: faço referência a Freud. ${ }^{33}$

Por outro lado, é interessante lembrar dos profundos estudos do filósofo Derrida sobre Freud e com Freud e até mesmo contra Freud. Alguns de seus textos: Freud e a cena da escritura (1967); O Carteiro da verdade (1980); Mal de arquivo (1994); Estados-da-alma da psicanálise (2000), ${ }^{34}$ o que para teoria psicanalítica não é pouco.

Mas Nietzsche, através de seu personagem que cria, Zaratustra, traz também a canalha [Da Canalha], os vermes e tarântulas [Das Tarântulas] - os ressentidos não criativos. Em algum momento intempestivo Nietzsche dirá: são os historiadores e os proclamados filósofos da política - guardiões de arquivos. Envenenaram as palavras.

$\mathrm{Na}$ passagem "Dos Homens Sublimes", Zaratustra registra os animais selvagens, um animal não subjugado: "Ei-lo sempre como um tigre preparando o salto; mas a mim não me agradam essas almas mesquinhas...". 35 Ainda sobre os ressentidos não criativos, aqueles que buscam vontade de verdade, vontade de Estado, Zaratustra continua seu ataque, utilizando-se de metáforas "animais" [Dos Grandes Acontecimentos]:

Igreja é uma espécie de Estado, e a mais enganosa. Cala-te, porém, cão hipócrita: tu conheces a tua raça melhor que

\footnotetext{
${ }^{32}$ DERRIDA, J. L'animal que donc je suis. Paris: Galilée, 2006, p. 17.

${ }^{33}$ Ver BIRMAN, J. Sujeito e estilo em psicanálise: sobre o indeterminismo da pulsão no discurso freudiano. In As Pulsões. São Paulo: Escuta, 1995.

${ }^{34}$ [Edições brasileiras: Freud e a Cena da Escritura. In A Escritura e a Diferença. Trad. Maria Beatriz Marques Nizza da Silva. São Paulo: Perspectiva, 2009; O Cartão-postal: de Sócrates a Freud e Além. Trad. Simone Perelson e Ana Valéria Lessa. Rio de Janeiro: Civilização Brasileira, 2007; Mal de Arquivo: uma Impressão Freudiana. Trad. Claudia de Moraes Rego. Rio de Janeiro: Relume Dumará, 2001; Estados-da-Alma da Psicanálise - O Impossível para Além da Soberana Crueldade. Trad. Antonio Romane \& Isabel Kahn Marin. São Paulo: Escuta, 2001.]

${ }^{35}$ NIETZSCHE. F. Assim falava Zaratustra. Trad. José Mendes de Souza. São Paulo: Brasil editora, 1965, p. 95.
} 
ninguém! O Estado é um cão hipócrita como tu; como a ti, agrada-lha falar fumegando.

E nesta vontade de verdade, o Estado empenha-se em ser o animal mais importante da Terra.

É o Caso Leviathan. O Leviathan $\left[\right.$ Liviatan ${ }^{36}$ na bíblia hebraica era um animal, um grande peixe, uma serpente perigosa. Tinha intensidade. Força. Vigor. Pode-se também interpretar este animal numa descrição onde estão reunidas todas as energias que nos outros animais só se encontram separadamente. O Leviathan é um superanimal [excesso de intensidade]. A luta que se trava no final dos tempos entre Leviathan e Behemoth, na qual ambos são mortalmente feridos, leva Deus a despedaça-los, preparando uma refeição para os Justos. ${ }^{37}$ A despeito de algumas obscuridades de significativo, nisso há apenas o fato de que o Leviathan invariavelmente aparece em imagens míticas poderosas na figura de um enorme animal aquático, semelhante a um crocodilo, uma baleia ou, em geral, como um peixe imenso, ao passo que Behemoth aparece como um animal terrestre, por exemplo, como um grande touro ou elefante. ${ }^{38}$ Mas, a oposição entre Deus e o monstro, revela durante os séculos que o enorme animal aquático separa-se em dois contrários [Leviathan $X$ Behemoth], libertando-se a divindade de seu conflito. O elemento conflituoso aparece como um par de monstros-irmãos adversários ou na Gestalt do inimigo. ${ }^{39}$

Devido a interpretação cristã por parte de Tomás Hobbes, séculos depois, de Carl Schmitt, o Leviathan foi transformado numa máquina - uma máquina que apaga todos os traços. A máquina Mestra ensina, "por si mesma, o encadeamento das multidões humanas, em operações em que cada um só tem de fazer uma coisa; ela

\footnotetext{
${ }^{36}$ JUNG. C.G. A Ambivalência do Símbolo de Peixes. In AION, estudos sobre o simbolismo do si-mesmo. Trad. Dom Mateus Ramalho. Petrópolis: Vozes, 2008, p. 163.

${ }^{37}$ Idem, p. 164.

${ }^{38}$ SCHMITT, C. O Leviatã na teoria do Estado de Thomas Hobbes - sentido e fracasso de um símbolo político. (1938) Trad. Cristiana Filizola \& João C. Galvão Jr. In GALVÃO JR. J.C. Leviathan cibernético - da quebra das máquinas ao Leviatã cibernético (Manifesto II). Rio de Janeiro: NPL, 2008, p. 192.

${ }^{39}$ JUNG. C.G. A Ambivalência do Símbolo de Peixes. In AION, estudos sobre o simbolismo do si-mesmo. Trad. Dom Mateus Ramalho. Petrópolis: Vozes, 2008, p. 164.
} 
fornece o modelo da organização de partido e da condução da guerra (...) faz de muitos uma só máquina, e de cada um, um instrumento para uma só meta”. ${ }^{4}$

"Símbolo Cristo" 41 [o poder se faz pela Seele] passa a substituir a figura de Leviathan, sob a forma de peixe. ${ }^{42}$

Perguntariam os historiadores ou guardiões: "Mas no século XVII não existia 'Nazismo!?" Pois é... faço das palavras de Frederico, as minhas: "Cala-te, cão hipócrita!”. À História pertence o movimento do eterno retorno. Nestes casos, retorno do mesmo. O Reitor Heidegger, ${ }^{43}$ como um bom nazista, estava certo. Como um bom cristão também [se é que culturalmente estes dois momentos possuem alguma diferança]. Ou são marcados pela identidade? Como vai lembrar Reich em "Análise do Caráter": "Explosões epidêmicas da peste emocional manifestam-se em pequena e grande escala. A Inquisição católica foi uma dessas explosões epidêmicas; o fascismo do século XX é outra". ${ }^{44}$ Todas marcadas por vontade de verdade na determinação, adestramento e eliminação do animal.

A peste emocional cultural da representação elimina forças demoníacas e espectrais.

Diante deste animal, do animal indeterminado, do animal que nos olha, diante da existência rebelde deste conceito, Derrida traz este importante alerta do adestramento do animal - da animalidade do/ no homem. Da animalidade do homem domesticada. Seguir e perseguir esta animalidade. Domar o animal. Derrida faz referência a Quimera [Chimère]. ${ }^{45}$ Quem foi e o que foi Quimera? Khimaira, monstro mitológico que se dizia possuir cabeça de leão, corpo de cabra e cauda de dragão ou

${ }^{40}$ NIETZSCHE, F. Humano, demasiado humano. Trad. Paulo César de Souza. São Paulo: Companhia das Letras, 2008, vol. II, p. 265 [HH II, II, § 218].

${ }^{41}$ JUNG. C.G. O Segredo da Flor de Ouro. Trad. Dora Ferreira da Silva e Maria Luíza Appy. Petrópolis: Vozes, 2007, p. 65.

${ }^{42}$ JUNG. C.G. A Ambivalência do Símbolo de Peixes. In AION, estudos sobre o simbolismo do si-mesmo. Trad. Dom Mateus Ramalho. Petrópolis: Vozes, 2008, p. 164.

${ }^{43}$ Ver os importantes estudos de FAYE, J-P. A Razão narrativa - a filosofia heideggeriana e o Nacional-Socialismo. Trad. Paula Martins, Henrique Antoun e Joaquim Humberto Oliveira. São Paulo: ed. 34, 1996.

${ }^{44}$ REICH, W. A Peste Emocional. In Análise do Caráter (1933) Trad. Ricardo Amaral do Rego. São Paulo: Martins Fontes, 1989, p. 461.

${ }^{45}$ DERRIDA, J. L'animal que donc je suis. Paris: Galilée, 2006, p. 66. 
serpente e lançar fogo pelas narinas, será morta pela figura de Belerofonte [Bellérophon]. ${ }^{46}$

Ele, Belerofonte ["Mestre ferrador" $\left.{ }^{47}\right]$ diria: eu sigo, eu persigo, caço e domo o animal. Palavras do Mestre ferrador, que fala em voz forte, num tom autoritário. $\mathrm{O}$ "estado de selvageria"48 passa ser a calma e a obediência.

Involuntariamente o Mestre ferrador ou Belerofonte voltou os olhos, inconscientemente interessado na fuga do bicho. É isso que Derrida quer anunciar em seu discurso filosófico: dos perigos do extermínio das intensidades. Esta animalidade deve ser domada pelo discurso do ser. "Belerofonte" [leia-se: "Lacan" ou "Jung" pensadores da representação] é um caçador, um caçador de animais. Persegue os dragões, doma o animal. Uma ordem militar instituída em 1118 em plena modernidade [pós-modernidade pela cibernética]. "Muitas cadeias [erros das concepções morais, religiosas, metafísicas] foram postas no homem, para que ele desaprendesse de se comportar como um animal." ${ }^{49}$ Anéis de ferro na voz do Mestre ferrador - obediência cega que pode persistir a vida toda.

Atenção para o Livro II $^{50}$ de Jacques Lacan, quando fala da cibernética ou da natureza da linguagem, $\operatorname{logo}(s)$ sobre a Máquina perfeita [técnica-teologia], um espaço de domesticação. "Epimeteu troca sua alma por um brinquedo mecânico" (grifo nosso). ${ }^{51}$ Espaço de eliminação, de apagamento, extinção dos viventes considerados não humanos. "Viventes não humanos" [vivants non humains]. ${ }^{52}$

\footnotetext{
${ }^{46}$ Idem.

${ }^{47}$ FERENCZI, S. Adestramento de um cavalo selvagem. Trad. Álvaro Cabral. In Psicanálise II, Obras Completas. São Paulo: Martins Fontes, 2011, vol. 2, p. 14.

${ }^{48}$ Idem, p. 13.

${ }^{49}$ NIETZSCHE, F. Humano, demasiado humano. Trad. Paulo César de Souza. São Paulo: Companhia das Letras, 2008, vol. II, p. 310 [HH II, II, § 350].

${ }^{50}$ LACAN, J. Psychanalyse et cybernétique, ou de la nature du langage (1955) In Le moi dans la théorie de Freud et dans la technique de la psychanalyse. Paris: Seuil, 1978, Livre II [edição brasileira: Psicanálise e Cibernética, ou da Natureza da Linguagem In O Eu na Teoria de Freud e na Técnica da Psicanálise. Trad. Marie Christine Lasnik Penot e Antonio Luis Quinet de Andrade. Rio de Janeiro: JZE, 1985, Livro 2].

${ }^{51}$ SPITTELER. C. Prometeu e Epimeteu. Trad. Manuel Bandeira. Rio de Janeiro: Opera Mundi, 1971, p. 34.

${ }^{52}$ DERRIDA, J. L`animal que donc je suis. Paris: Galilée, 2006, p. 56.
} 
Como registrou Chaim Samuel Katz, num texto marcante: "Exclusão e segregação das idéias, apagamento de diferenças em nome do 'começo originário': esta é sempre uma marca fascista". 53

O monstro que cuspia fogo - cuspia intensidades - em linguagem mística seria um ser que simboliza o poder do mal, o inimigo do gênero humano, um diabo. Um demônio que deve ser detido pelo freio das cadeias. "Forças espectrais e demoníacas". ${ }^{54}$ Eles, os humanos $\left[\right.$ ils, les humains ${ }^{55}$ se deram a "decisão" de eliminar os animais que logo somos.

Este animal, fala, ainda? Quer falar? Este animal, deseja? Quer desejar?

É interessante observar ainda, na edição francesa do texto de Derrida, L'animal que donc je suis, que a parte III, "E se o animal responder?” [Et si l'animal répondait?] é dedicada à Lacan - à Jacques Lacan.

O animal em "Lacan" [pensadores da representação], fala?

Poucos pensadores. Pouca Filosofia. Pouca filosofia. Pouco pensar. Pouca ação. Nenhuma criatividade.

Mas - nós - estávamos aonde? Em nenhum lugar. Estávamos descendo a montanha com Zaratustra. Estávamos começando a soltar os animais que logo somos; criando um diálogo com os animais - seus animais - nossos animais. Teu animal.

Em A Hora Silenciosa ${ }^{56}$, o urso regressa sem alegria. "Ter o poder e não querer reinar, o mais indesculpável em ti”. Falta a voz do leão para mandar.

Depois de muitas viagens solitárias, o trepador de montanhas, em seu regresso $\left[\begin{array}{ll}O & \text { Regresso }\end{array}\right]^{57}$, liberta seu nariz do cheiro do ser humano, de todos os viventes humanos. Entre estes viventes, tudo fala: já ninguém sabe compreender. Tudo fala e nada se ouve.

Ao destruidor - a esse é que chamam animal.

\footnotetext{
${ }^{53}$ KATZ, C.S. Psicanálise e Nazismo. Rio de Janeiro: Taurus, 1985, p. 280.

${ }^{54}$ BENJAMIN, W. Mundo e tempo (1919) (Fragmentos: Filosofia da História e Política). In $O$ Anjo da História. Trad. João Barrento. Lisboa: Assírio \& Alvim, 2010, vol. 4, p. 30 (Versão preparatória do ensaio perdido sobre "O Verdadeiro Político").

${ }_{55}^{5}$ DERRIDA, J. L'animal que donc je suis. Paris: Galilée, 2006, p. 56.

${ }^{56}$ NIETZSCHE. F. Assim falava Zaratustra. Trad. José Mendes de Souza. São Paulo: Brasil editora, 1965, p. 120 - 122.

${ }^{57}$ Idem, p. 150.
} 
O Diabo que abre tudo o que se encontra fechado - forças demoníacas. É o destruidor em que tudo é reduzido a nada. ${ }^{58}$

Uma manhã, depois de seu regresso, Zaratustra saltou do leito como um louco: começou a gritar com voz terrível; e a voz de Zaratustra troava, uma sinistra voz, que os seus animais fugiram, voando, arrastando-se e saltando.

Mas os seus animais não o abandonaram nem de dia nem de noite, a não ser quando a águia percorria os ares em busca de alimento. Nos pés de Zaratustra estavam estendidas duas ovelhas que a águia roubara dos humanos pastores.

Que estes homens, este homem que grita, solta a voz, é o mais cruel de todos os animais.

E tornaram a passar meses e anos, seus cabelos faziam-se-lhe brancos, mas seus animais, pensativos, andavam em torno dele e acabaram por se lhe por em frente. - "Mas, não queres subir hoje a uma alta montanha? O ar permite passagens da luz, e hoje vê-se o mundo melhor do que nunca". - "Sim, animais meus" 59 - respondeu Zaratustra.

Seus animas indicam a necessidade à maravilha do seu desejo.

O animal e o desejo, o desejo e o animal, o animal do desejo, o desejo do animal.

Um mundo povoado de animas, de delícias de todos os ferozes cassadores [Mestre ferrador]. Ó meus amigos. ${ }^{60}$ - os amigos já conhecem na Teoria psicanalítica quem foi Belerofonte [Bellérophon], digo, na "Teologia política" ou Filosofia da representação. E é difícil estabelecer se essa truculenta técnica de adestramento do animal atravessada pela linguagem falada [leia-se: inconsciente humanizado] pode prejudicar em seguida sua saúde. ${ }^{61}$ Este tipo de adestramento só tem interesse para animais domesticados cuja principal qualidade é a docilidade. ${ }^{62}$

\footnotetext{
${ }^{58}$ JUNG. C.G. Septem Sermones ad Mortuos (1916). Rio de Janeiro: Nova Fronteira, 1988, p. 338.

${ }^{59}$ Idem, [A Oferta de Mel], p. 194 - 197.

60 "O mes amis, il n'y a nul amy". DERRIDA, J. Politiques de l'amitié. Paris: Galilée, 1994, p. 17. Ver a polêmica desta expressão em AGAMBEN, G. L'amitié. Traduit Martin Rueff. Paris: Payot, 2007, p. 11.

${ }^{61}$ FERENCZI, S. Adestramento de um cavalo selvagem. Trad. Álvaro Cabral. In Psicanálise II, Obras Completas. São Paulo: Martins Fontes, 2011, vol. 2, p. 18.

${ }^{62}$ Idem, p. 17.
} 
O mundo dos homens, o mar dos homens - vamos abrir este abismo humano. Vamos abrir as portas desta cidade com as devidas hordas e suas intensidades. Vamos abrir a História - passagens para história. História aberta.

Trazer para esta história peixes e caranguejos, tubarões e crocodilos. Todos os bichos que habitam o deserto. A linguagem não é a casa do ser. A linguagem é a casa dos seres. Os crocodilos sabem reconhecer o movimento repetitivo de sua presa na água; os tubarões, não oferecem perigo ao homem [homem humanizado], muito embora sua carne seja muito consumida (mas de uma forma ou de outra, a forma é idêntica nesta civilização [cultura], o outro do outro, considerado um vivente não humano, foi exterminado pelo movimento do Espírito). O outro do outro [forças espectrais] não existe para Belerofonte [Bellérophon]. As abelhas africanizadas atacam em massa. Por que será que estas abelhas migraram [atacaram] para os U.S.A.? O ataque, neste caso que não é a de um Caso humano [ideologizado] - é um Caso "animal” ou animot.

Nesta abertura, descendo ou subindo a montanha, com meu animal, meus animais, teu animal - nossos animais, marcar a(s) animalidade(s) que nos olha como um espectro. Espectros que poderiam ou podem ser vistos melhor com a lente da psicanálise, da teoria psicanalítica e da literatura barroca. O "Mundo dos espectros" ${ }^{63} \mathrm{e}$ seu Tempo - de spectris - envolvendo esta questão no trauerspiel benjaminiano.

"Mas afinal de contas por que não deveria haver fantasmas?". ${ }^{64}$

Soltando os animais que logo somos, abrindo a(s) porta(s) deste reino, quando Zaratustra deu a volta, mudou repentinamente a paisagem, e Zaratustra entrou no reino da morte. Surgiram ali negros e vermelhos penhascos, e não havia erva, árvores, nem o canto de pássaros. Era um reino que todos os animais desprezavam, até as feras, até mesmo o mais forte leão; só uma espécie muito feia de grandes cobras verdes ia ali morar, quando envelhecia.

Mas o que Zaratustra ouve no reino da morte é o som da voz humana e humana palavra. ${ }^{65}$ Esta humana palavra dorme enquanto Zaratustra está acordado. Os animais de Zaratustra estão acordados. "Chega o sinal" ${ }^{66}$, disse Zaratustra. E Zaratustra

\footnotetext{
${ }^{63}$ BENJAMIN, W. Origem do Drama Trágico Alemão. Trad. João Barrento. Lisboa: Assírio \& Alvim, 2004, p. 139.

${ }^{64}$ JUNG. C.G. Anos de Estudo. In Memórias, Sonhos, Reflexões. Trad. Dora Ferreira da Silva. Rio de Janeiro: Nova Fronteira, 1988, p. 96.

${ }^{65}$ NIETZSCHE. F. [O Homem Mais Feio] Assim falava Zaratustra., p. 215 - 220.

${ }^{66}$ NIETZSCHE. F. [O Sinal], p. 266 - 268.
} 
viu diante de si, um corpulento animal ruivo, que encostava a cabeça aos seus joelhos. Vendo tudo isso, Zaratustra só disse uma coisa: "Estão perto os meus filhos",67. E depois disso emudeceu completamente.

Os filhos de Zaratustra não tardam: chega o leão. Magnífico como o leão no momento em que ataca a vítima. Nobre animal, como nenhum outro existe sobre a terra.

Em outra direção, numa posição de representação, presente em Prometeu [leia-se: Spitteler], quando num primeiro momento abandona seus animais - seu leão ${ }^{68}$ reunindo este seus últimos restos de vida e caindo morto; "E em seguida foi enterrar o leão num canto do jardim". ${ }^{69}$ Num segundo momento ("Reviravolta"), ${ }^{70}$ quando o leão retorna, aparece arrastando-se em uma melancólica alegria, mas seu "mestre e senhor" [Prometeu] abandona-o novamente deixando-o cair sem ruído ao fundo da cova. Eliminando sua animalidade de vez, declara Prometeu: “ ... não possuo nenhum cão, e se algum traz coleira com o meu nome, tal sinal terá sido roubado. Deve ser algum cão perdido que eu poupei por compaixão, e a não ser isso, nada me liga a ele, e o que quer que ele faça ou deixe de fazer, terá sido sem o meu conselho, e se ele cometer pecados, loucuras ou inconveniências, seja ele o único responsável e o único punido, sem a minha proteção ou apoio". ${ }^{71}$

O processo que está na base desta epopéia mitológica [spittelerianajunguiana] é a do mundo como punição [o cenário da História como punição]. A nomeada humanidade está domada numa infinita repetição do mito [repetição do mesmo]. ${ }^{72}$

Registra Benjamin que "muito antes de os símbolos arcaicos, o culto e a magia mortuários, os ritos da terra, terem despertado a atenção, não apenas dos investigadores da mentalidade primitiva, mas também dos psicólogos freudianos [leia-se: C.G. Jung] e dos letrados em geral", 73 J.J. Bachofen, cientista suíço, traçara um quadro da pré-

\footnotetext{
${ }^{67}$ Idem.

${ }^{68}$ SPITTELER. C. O Leão. In Prometeu e Epimeteu. Trad. Manuel Bandeira. Rio de Janeiro: Opera Mundi, 1971, p. 116.

${ }^{69}$ Idem.

${ }^{70}$ Idem, p. 320.

${ }^{71}$ Idem, p. 333.

${ }^{72}$ BENJAMIN, W. Paralipômenos, reflexões preparatórias, fragmentos. In O Anjo da História. Trad. João Barrento. Lisboa: Assírio \& Alvim, 2010, vol. 4, p. 156 (As passagens cortadas por Benjamin nos originais de "Sobre o conceito da História", Novas teses C.).

${ }^{73}$ BENJAMIN, W. Johann Jakob Bachofen (1934-35) In O Anjo da História. Trad. João Barrento. Lisboa: Assírio \& Alvim, 2010, vol. 4, p. 80.
} 
história que colocava de lado tudo o que o senso comum do século XIX imaginava sobre as origens da religião, gerando grande interesse nos teorizadores do fascismo. $\mathrm{O}$ que desde logo se estabelece são os símbolos arcaicos na base do pensamento e da vida cultural. O Espírito [cristalizações dos símbolos] como adversário da alma [psíquico], "sistema, aliás, sem saída, e que se perde numa profecia ameaçadora dirigida aos humanos que se deixaram cegar pelas insinuações do espírito" "74 $\mathrm{O}$ que Jung reifica em seu pensamento arcaico da representação [leia-se: fidelidade à crença cristã] na cristalização das imagens é o que historicamente se revela na Alemanha nazi-fascista do século XX: o renascimento [retorno] do mito branco. O seu cristianismo enraizado no Livro da Bíblia mergulha-se na mais profunda especulação dos símbolos. O pensamento "Ocidental" [discurso dos vencedores] reifica e representa inconscientemente a imagem deste mito [imagem do mito].

A animalidade [forças espectrais e demoníacas] que este pensamento da representação sonega e só nega [elimina], desde a criação de um mito branco ["Mitologia branca",75], capturando os animais, nesta Odisséia [Odisséia animot] - sobre os "animais", Derrida traz a questão das "Violências contra animais", 76 da violência industrial, científica, técnica, que não será suportável por muito tempo. Que não será suportável por muito tempo - retorno animot. A forma pela qual a auto-proclamada Filosofia [pensamento da representação], em seu conjunto, hegemônico [hegemonia], ${ }^{77}$ tratou a questão falada [ou das muitas vozes] do "animal" é um signo do logocentrismo e de uma limitação desconstrutível da/ na Filosofia.

Talvez seja por isso que Derrida inicie sua Grammatologie com a seguinte epígrafe ou inscrição do criador do profeta Zaratustra:

Socrate, celui qui n'écrit pas ${ }^{78}$

\footnotetext{
${ }^{74}$ Idem, p. 89 - 90.

${ }^{75}$ DERRIDA, J. A Mitologia Branca. In Margens da Filosofia. Trad. Joaquim Torres Costa \& António M. Magalhães. Porto: Rés, s/ data, p. 265 - 354.

${ }^{76}$ DERRIDA, J. De que amanhã ... Trad. André Telles. Rio de Janeiro: JZE, 2004, p. 80 - 96.

${ }^{77}$ Supremacia ou superioridade (cultural, econômica ou militar) de um povo ou cidade-estado nas federações da Grécia antiga.

${ }^{78}$ DERRIDA, J. De la grammatologie. (1967). Paris: Minuit, 2006, p. 15: "Sócrates, aquele que não escreve".
} 
"Sócrates" - o animal domesticado. A presença desta serpente negra e pesada já anunciava o mito do herói falante durante os séculos até a modernidade. Belerofonte [Bellérophon] é profundo conhecedor deste mito falante.

"A cada alma pertence um mundo diferente; para cada alma, toda outra alma é um além-mundo" [O Convalescente $]{ }^{79}$ É preciso morder a cabeça desta serpente, destruir este niilismo passivo e negativo; "mas de uma dentada cortei-lhe a cabeça e cuspi-a para longe de mim!". 80

No pensamento Ocidental, "o que" "fala" em Nietzsche, Freud e Benjamin são os animais; quem "fala" em Hegel, Heidegger, Jung, Lacan, Schmitt etc é o Espírito [ou a imagem imaginária do mesmo].

O que diremos de um "Derrida"?

Aparência de liberdade [Freischeinllichkeit] mas não liberdade - a "árvore do conhecimento" não pode ser confundida com a "árvore da vida" .

Para finalizar sem finalizar, com Derrida ou sem Derrida, e até mesmo contra Derrida: Derrida registra nas primeiras páginas de seu texto o "instinto do animal autobiográfico" [l'instinct de l'animal autobiographique $]{ }^{81}$ texto marcado, que deixa uma marca pessoal do autor, uma espécie sem espécie de uma "zoo-auto-bio-bibliographie"; 82 uma cena autobiográfica necessitando de uma psique [psyché]. ${ }^{83}$

O animal ou animais [não] são capturados pelo espelho. "E se tu agora quisesse morrer, Zaratustra, também sabemos como falarias a ti mesmo; mas os teus animais te suplicam não morras ainda" ${ }^{84}$ Teus instintos, não morram ainda.

Quando isso me olha, quando isso me cheira, quando isso me rosna, quando isso se expressa, quando isso não representa esse vivente humanizado; quando isso leão ou gato [da não possibilidade de separação do animal ou homem ou de sua animalidade]; quando isso: instintualmente seres de linguagem como expressão, sem mediações e representações, não tem o mínimo interesse em ser compreendido pelo discurso do "Ser" [de sua casa e habitação]. A linguagem das coisas já é linguagem

\footnotetext{
${ }^{79}$ NIETZSCHE. F. Assim falava Zaratustra. Trad. José Mendes de Souza. São Paulo: Brasil editora, 1965, p. 180.

${ }^{80}$ Idem.

${ }^{81}$ DERRIDA, J. L'animal que donc je suis. Paris: Galilée, 2006, p. 16.

${ }^{82}$ Idem, p. 57.

${ }^{83}$ Idem, p. 76.

${ }^{84}$ NIETZSCHE. F. [O Convalescente] Assim falava Zaratustra, p. 183.
} 
animot, é manifestação de forças espectrais e demoníacas. "Tão forte como este impulso destrutivo é na autêntica historiografia o impulso para a salvação [Rettung]" (grifo nosso). ${ }^{86}$

Este inconsciente instintual não pode ser capturado pelo "grande espelho"; é rememoração das intensidades "perdidas" em sua salvação a cada instante presente do agora.

Mas como dirá Derrida:

Je ne suis pas Benjamin, quand je me trouve nu au regard de l'animal, je ne suis pas prêt à le suivre dans cette belle méditation écrite en plein milieu de la première guerre mondiale, en $1916 .^{87}$

Esta "bela meditação" que Derrida faz ref(v)erência chama-se: Über Sprache überhaupt und über die Sprache des Menschen - "Sobre a linguagem em geral e a linguagem do homem. ${ }^{88}$

Mas isso é outra história... [Outra história?]

${ }^{85}$ BENJAMIN, W. Mundo e tempo (1919) (Fragmentos: Filosofia da História e Política). In $O$ Anjo da História. Trad. João Barrento. Lisboa: Assírio \& Alvim, 2010, vol. 4, p. 30 (Versão preparatória do ensaio perdido sobre "O Verdadeiro Político").

${ }^{86}$ BENJAMIN, W. Paralipômenos, reflexões preparatórias, fragmentos. In O Anjo da História. Trad. João Barrento. Lisboa: Assírio \& Alvim, 2010, vol. 4, p. 163 (As passagens cortadas por Benjamin nos originais de "Sobre o conceito da História", Fragmentos sem título, manuscrito 473).

${ }^{87}$ DERRIDA, J. L'animal que donc je suis. Paris: Galilée, 2006, p. 39. [Não sou Benjamin, quando me encontro nu diante do olhar do animal, não estou disposto a segui-lo nessa bela meditação escrita em 1916, em plena Primeira Guerra Mundial].

${ }^{88}$ BENJAMIN, W. Sur le langage en général et sur le langage humain (1916). Trad. par Maurice de Gandillac. In Oeuvres I, Paris: Gallimard, 2000, p. 142 - 165. 


\section{Referências}

AQUINO, T. A Imagem. (Questão 35) In Suma Teológica (Summae Theologiae). São Paulo: Loyola, 2003, vol. I.

BENJAMIN, W. Johann Jakob Bachofen (1934-35) In O Anjo da História. Trad. João Barrento. Lisboa: Assírio \& Alvim, 2010, vol. 4.

BENJAMIN, W. Mundo e Tempo (1919) (Fragmentos: Filosofia da História e Política). In O Anjo da História. Trad. João Barrento. Lisboa: Assírio \& Alvim, 2010, vol. 4 (Versão preparatória do ensaio perdido sobre "O Verdadeiro Político”).

BENJAMIN, W. Origem do Drama Trágico Alemão. Trad. João Barrento. Lisboa: Assírio \& Alvim, 2004.

BENJAMIN, W. Paralipômenos, reflexões preparatórias, fragmentos. In O Anjo da História. Trad. João Barrento. Lisboa: Assírio \& Alvim, 2010, vol. 4 (As passagens cortadas por Benjamin nos originais de "Sobre o conceito da História".)

BENJAMIN, W. Sur le langage en général et sur le langage humain (1916). Trad. par Maurice de Gandillac. In Oeuvres I, Paris: Gallimard, 2000.

BIRMAN, J. Je suis vu, donc je suis: la visibilité en question. In Les Tyrannies de la visibilité. Paris: Érès, 2011.

BIRMAN, J. Sujeito e estilo em psicanálise: sobre o indeterminismo da pulsão no discurso freudiano. In As Pulsões. São Paulo: Escuta, 1995.

DERRIDA, J. De la grammatologie. (1967). Paris: Minuit, 2006.

DERRIDA, J. De que amanhã ... Trad. André Telles. Rio de Janeiro: JZE, 2004.

DERRIDA, J. Et si l'animal répondait? In L'animal que donc je suis. Paris: Galilée, 2006.

DERRIDA, J. Margens da Filosofia. Trad. Joaquim Torres Costa \& António M. Magalhães. Porto: Rés, s/ data.

DERRIDA, J. O Animal que Logo Sou. Trad. Fábio Landa. São Paulo: UNESP, 2002.

DERRIDA, J. Politiques de l'amitié. Paris: Galilée, 1994.

FAYE, J-P. A Razão narrativa - a filosofia heideggeriana e o Nacional-Socialismo. Trad. Paula Martins, Henrique Antoun e Joaquim Humberto Oliveira. São Paulo: ed. 34, 1996. 
FERENCZI, S. Adestramento de um cavalo selvagem. Trad. Álvaro Cabral. In Psicanálise II, Obras Completas. São Paulo: Martins Fontes, 2011, vol. 2.

FERENCZI, S. Crítica de metamorfoses e símbolos da libido, de Jung. Trad. Álvaro Cabral. In Psicanálise II, Obras Completas. São Paulo: Martins Fontes, 2011, vol. 2.

FREUD, S. El malestar en la Cultura. Trad. José L. Etcheverry. In Obras Completas. Buenos Aires / Madrid: Amorrortu, 2007, vol. 21.

FREUD, S. El porvenir de una Ilusión. Trad. José L. Etcheverry. In Obras Completas. Buenos Aires / Madrid: Amorrortu, 2007, vol. 21.

FREUD, S. Una dificultad del psicoanálisis (1916) Trad. José L. Etcheverry. In Obras Completas. Buenos Aires / Madrid: Amorrortu, 2007, vol. 17.

JUNG. C.G. A Ambivalência do Símbolo de Peixes. In AION, estudos sobre o simbolismo do si-mesmo. Trad. Dom Mateus Ramalho. Petrópolis: Vozes, 2008.

JUNG. C.G. Cartas (1946 - 1955). Trad. Edgar Orth. Petrópolis: Vozes, 2002, vol. 2.

JUNG. C.G. Memórias, Sonhos, Reflexões. Trad. Dora Ferreira da Silva. Rio de Janeiro: Nova Fronteira, 1988.

JUNG. C.G. O Livro Vermelho: Liber Novus. Trad. Edgar Orth. Petrópolis: Vozes, 2010.

JUNG. C.G. O Segredo da Flor de Ouro. Trad. Dora Ferreira da Silva e Maria Luíza Appy. Petrópolis: Vozes, 2007.

JUNG. C.G. Septem Sermones ad Mortuos (1916). Rio de Janeiro: Nova Fronteira, 1988.

JUNG. C.G. Símbolos da Transformação - Análise dos prelúdios de uma esquizofrenia (1952) Trad. Eva Stern. Petrópolis: Vozes, 1995.

KATZ, C.S. Psicanálise e Nazismo. Rio de Janeiro: Taurus, 1985.

KATZ, C.S. “Seminário sobre a Técnica Psicanalítica”. Notas do curso ministrado por Chaim Samuel Katz na Formação Freudiana - F.F, Rio de Janeiro, março-novembro de 2010.

LACAN, J. Le stade du miroir comme formateur de la fonction du Je (1936-49) In Écrits. Paris: Seuil, 1966.

LACAN, J. Psychanalyse et cybernétique, ou de la nature du langage (1955) In Le moi dans la théorie de Freud et dans la technique de la psychanalyse. Paris: Seuil, 1978, Livre II. 
LACAN, J. Propos sur la causalité psychique (1946) In Écrits. Paris: Seuil, 1966.

NIETZSCHE. F. Assim Falava Zaratustra. Trad. José Mendes de Souza. São Paulo: Brasil editora, 1965.

NIETZSCHE. F. Ecce Homo: como alguém se torna o que é. Trad. Paulo César de Souza. São Paulo: Companhia das Letras, 2003.

NIETZSCHE, F. Humano, demasiado humano. Trad. Paulo César de Souza. São Paulo: Companhia das Letras, 2008, vol. II.

REICH, W. A Peste emocional. In Análise do Caráter (1933) Trad. Ricardo Amaral do Rego. São Paulo: Martins Fontes, 1989.

SCHMITT, C. O Leviatã na teoria do Estado de Thomas Hobbes - sentido e fracasso de um símbolo político. (1938) Trad. Cristiana Filizola \& João C. Galvão Jr. In GALVÃO JR. J.C. Leviathan cibernético - da quebra das máquinas ao Leviatã cibernético (Manifesto II). Rio de Janeiro: NPL, 2008.

SPITTELER. C. Prometeu e Epimeteu. Trad. Manuel Bandeira. Rio de Janeiro: Opera Mundi, 1971. 